\title{
Production of Cellulase by Soil Isolated Streptomyces sp.
}

\author{
Mery S. Waheeb ${ }^{a}$, Walid F. Elkhatib ${ }^{a, b}$, Mahmoud A. Yassien ${ }^{a}$, Nadia A. Hassouna ${ }^{a}$ \\ ${ }^{a}$ Department of Microbiology and Immunology, Faculty of Pharmacy, Ain Shams University, Cairo 11566, Egypt \\ ${ }^{\mathrm{b}}$ Department of Microbiology and Immunology, Faculty of Pharmacy, Galala University, New Galala city, Suez, \\ Egypt
}

\begin{abstract}
Cellulases have been considered effective biocatalysts because of their diversity of applications. A total of 165 cellulase-producing Streptomyces isolates were recovered from Egyptian soil samples via cultivation on carboxymethyl cellulose agar medium. The results of screening by the Congo red method showed that the tested isolates revealed different levels of cellulase activity. The isolates showed a high level of cellulase production (clear zones $>25 \mathrm{~mm}, \mathrm{n}=15$ ) were submitted for quantitative evaluation of their cellulase productivities by using dinitrosalicylic acid assay. Cellulase production of these selected isolates ranged from 146.9 to $650.5 \mathrm{U} / \mathrm{L}$. The highest cellulase-producing isolate (S11-6) was identified at the molecular level using 16S rRNA gene sequencing. The sequence homology analysis proved its proximity and relatedness to Streptomyces coelicoflavus strain NBRC 15399. Production improvement of cellulase was carried out by genetic manipulation using a dose of 4 Kilogray (KGy) of gamma radiation. M1 mutant showed 1.31 fold increments in cellulase production as compared to the wild-type strain of $S$. coelicoflavus.
\end{abstract}

Keywords: cellulose; Streptomyces coelicoflavus; dinitrosalicylic essay; genetic manipulation; gamma radiation.

*Correspondence | Mahmoud A. Yassien; Department of Microbiology and Immunology, Faculty of Pharmacy, Ain Shams University, 11566 Cairo, Egypt. Email: myassien61@yahoo.com

Citation | Waheeb MS, Elkhatib WF, Yassien MA, Hassouna NA, 2021. Production of Cellulase by Soil Isolated Streptomyces sp. Arch Pharm Sci ASU 5(2): 225-233

DOI: 10.21608 /aps.2021.92280.1067

Print ISSN: 2356-8380. Online ISSN: 2356-8399.

Received 23 August 2021. Accepted 16 September 2021.

Copyright: ${ }^{\circledR} 2021$ Waheeb et al. This is an open-access article licensed under a Creative Commons Attribution 4.0 International License (CC BY 4.0), which permits unrestricted use, distribution, and reproduction in any medium, provided the original author(s) and source are credited.

Published by: Ain Shams University, Faculty of Pharmacy

\section{INTRODUCTION}

Cellulase is one of the most important industrial enzymes. They are used in the textile industry for bio-polishing and stone washing [1]; in beverage for enhancing extraction and filtration [2]; in the food industry for the improvement of juice and oil production [3]; in the pulp and paper industries for better drainage and fiber improvement [4], and they are even used for pharmaceutical applications [5].

The increasing concerns about fossil fuel depletion, greenhouse gas emissions, and air pollution caused by incomplete fossil fuel burning resulted in a growing emphasis on the synthesis of bioethanol from lingo-cellulosic biomasses [6]. Cellulases have sparked renewed attention in recent years, owing to their role in converting cellulosic biomass into industrially viable products or fuels. Agricultural byproducts, industrial waste, municipal rubbish, and other sources account for the majority of cellulosic biomass [7]. The elimination of these wastes is crucial for a variety of industries. Sugars, bioethanol, bio-methane, bio-hydrogen, and other chemicals could be manufactured from 
them [8]. Several microbes, most often bacteria and fungus, synthesize this enzyme [9]. Streptomyces sp. is one of the best-known enzyme producers [10].

The aim of the present study involved the isolation of high-cellulase-producing streptomycetal isolate(s) from Egyptian soil samples and improving its cellulase production through genetic manipulation.

\section{MATERIALS and METHODS}

\subsection{Isolation of Cellulase Producing Bacteria}

A total of 43 soil samples were collected from different Egyptian governorates. The samples were stored at $4{ }^{\circ} \mathrm{C}$ in sterile containers until use [11]. Ten-fold serial dilutions were prepared from each sample. Then $0.1 \mathrm{~mL}$ from each dilution was plated on carboxymethyl cellulose (CMC) agar plate $\left(1.0 \mathrm{~g} \mathrm{KH}_{2} \mathrm{PO}_{4}, 0.5 \mathrm{~g}\right.$ $\mathrm{MgSO}_{4} \cdot 7 \mathrm{H}_{2} \mathrm{O}, 0.5 \mathrm{~g} \mathrm{NaCl}, 0.01 \mathrm{~g} \mathrm{FeSO}_{4} \cdot 7 \mathrm{H}_{2} \mathrm{O}$, $0.01 \mathrm{~g} \mathrm{MnSO}_{4} \cdot 7 \mathrm{H}_{2} \mathrm{O}, 0.3 \mathrm{~g} \mathrm{NH}_{4} \mathrm{NO}_{3}, 10.0 \mathrm{~g}$ CMC, 30.0 g agar per liter, $\mathrm{pH} 7$ ) and incubated at 28 and $37{ }^{\circ} \mathrm{C}$ for $96 \mathrm{~h}$ [12]. Morphologically different colonies were isolated, purified, and stored on $\mathrm{CMC}$ agar plates at $4{ }^{\circ} \mathrm{C}$.

\subsection{Ability of the Collected Streptomyces Isolates for Cellulase Production by Congo Red Method}

The selected isolates were cultured on CMC agar plates that were incubated at $28{ }^{\circ} \mathrm{C}$ for $96 \mathrm{~h}$. After incubation, the plates were flooded with $0.1 \%$ Congo red for $20 \mathrm{~min}$ then washed with $1 \mathrm{M}$ $\mathrm{NaCl}$ for $30 \mathrm{~min}$ and the clearance zones (indicated CMC hydrolysis) formed around each colony were measured [13]. According to the size of formed clear zones, the isolates were divided into five groups; very strong ( $>25 \mathrm{~mm})$, strong (15-25 mm), moderate $(10-15 \mathrm{~mm})$, weak (5-10 $\mathrm{mm})$, and very weak (0-5 mm) [14].

\subsection{Conditions of Bacterial Growth and Enzyme Production}

Five-day-old cultures of the very strong producers were used to prepare a spore suspension in $10 \mathrm{~mL}$ sterile distilled water. Afterward, $0.5 \mathrm{ml}$ of this suspension was used to inoculate $50 \mathrm{~mL}$ CMC liquid medium $(1.0 \mathrm{~g}$ $\mathrm{KH}_{2} \mathrm{PO}_{4}, 0.5 \mathrm{~g} \mathrm{MgSO}_{4} \cdot 7 \mathrm{H}_{2} \mathrm{O}, 0.5 \mathrm{~g} \mathrm{NaCl}, 0.01 \mathrm{~g}$ $\mathrm{FeSO}_{4} \cdot 7 \mathrm{H}_{2} \mathrm{O}, \quad 0.01 \mathrm{~g} \quad \mathrm{MnSO}_{4} \cdot 7 \mathrm{H}_{2} \mathrm{O}, \quad 0.3 \mathrm{~g}$ $\mathrm{NH}_{4} \mathrm{NO}_{3}, 10.0 \mathrm{~g} \mathrm{CMC}$ per liter, $\mathrm{pH}$ 7) in $250 \mathrm{~mL}$ Erlenmeyer flasks and incubated in a shaking incubator (C25, New Brunswick Scientific, USA) at $200 \mathrm{rpm}$ and $28{ }^{\circ} \mathrm{C}$ for $96 \mathrm{~h}$. At the end of the incubation period, a known volume of the broth was centrifuged at $6000 \mathrm{~g}$ for $20 \mathrm{~min}$. The cell pellets were washed using sterile saline and dried in a hot oven at $60{ }^{\circ} \mathrm{C}$ to a constant weight. The supernatant was used for the determination of cellulase activity as described below $[\mathbf{5}, \mathbf{1 2}]$.

\subsection{Enzyme Assay}

The crude enzyme $(0.4 \mathrm{~mL})$ was added to 1.6 $\mathrm{ml}$ of $0.5 \% \mathrm{CMC}$ in $50 \mathrm{mM}$ sodium phosphate buffer ( $\mathrm{pH}$ 7). The reaction mixture was incubated for $30 \mathrm{~min}$ at $50{ }^{\circ} \mathrm{C}$ in a shaking water bath (GFL, Germany). Then the reaction was ended by adding $3 \mathrm{~mL} \mathrm{3,5-dinitrosalicylic} \mathrm{acid}$ (DNS) reagent. Then the mixture was boiled for 5 min to develop the color. To stabilize the color, 1 $\mathrm{ml}$ of $40 \%$ potassium sodium tartrate and then cooled. The optical densities (OD) were measured at $540 \mathrm{~nm}$ against a blank that contained the entire reagent without the crude enzyme. Results were determined in terms of cellulase activity in which the amount of cellulase that liberates $1 \mu \mathrm{mol}$ glucose per minute under the above assay conditions was defined as one unit $(\mathrm{U})$ of cellulase activity $[15,16]$.

\subsection{Molecular Identification of the Selected Isolate by $16 S$ rRNA Analysis}

The isolate with the highest cellulase activity was selected to be identified by $16 \mathrm{~S}$ rRNA gene sequence analysis. DNA extraction, PCR amplification of the 16S rRNA gene, and 
sequencing took place at Sigma Scientific Co. (Cairo, Egypt). The two primers used for PCR amplification of the 16S rRNA gene are StrepF: 5-ACGTGTGCAGCCCAAGACA-3 and StrepR: 5-ACAAGCCCTGGAAACGGGGT-3. To determine the degree of DNA similarity and sequence alignment, the BLAST search tool (http://blast.ncbi.nlm.nih.gov/Blast.cgi) was employed. The TREE VIEW program was used to align the sequences and create a neighborjoining phylogenetic tree [17].

\subsection{Improvement of Cellulase Production by Gamma Irradiation}

This was performed by exposure of the selected Streptomyces isolate to Gamma radiation as described by Khaliq et al [18] with a few modifications; a five-day-old culture of the chosen isolate was used to prepare a bacterial suspension of $1 \times 10^{8} \mathrm{CFU} / \mathrm{mL}$. To find the best dose for killing 99.99 percent of the bacteria, the resulting suspension was irradiated with various doses of gamma radiation (1, 2, 3, 4, and 5 Kilo Gray (KGy)). At the time of the experiment, the source of gamma radiation was ${ }^{60} \mathrm{Co}$ from an Indian Gamma cell that was generating a dose rate of $1.43 \mathrm{KGy} / \mathrm{h}$. The process was carried out at the National Center for Radiation Research and Technology, Atomic Energy Authority, Nasr City, Cairo, Egypt. The irradiated cell suspension was then diluted appropriately, plated on $\mathrm{CMC}$ plates, and cultured for 7 days at $28{ }^{\circ} \mathrm{C}$. Colonies were randomly chosen, purified, and kept on CMC slants.

Using the Congo red staining method, the cellulase productivity of the chosen colonies was compared to that of the wild-type strain. After that, the enzyme productivity of the resultant colonies with larger clearance zones was quantitatively evaluated using DNS assay.

\section{RESULTS}

\subsection{Isolation of Cellulolytic Bacteria from}

\section{Different Soil and Compost Samples}

A total of 165 cellulolytic bacterial isolates (they cultured on CMC agar medium which is selective for cellulase producers) were recovered from 43 soil samples from different Egyptian governorates at $28{ }^{\circ} \mathrm{C}$. They demonstrated the typical growth of Streptomyces species (colorful chalky appearance with hard textures).

\subsection{Ability of the Collected Streptomyces Isolates for Cellulase Production}

The Congo red technique was used to assess the recovered Streptomyces isolates for their capacities to generate cellulase (Fig. 1). Streptomyces isolates produced cellulase at different levels and they were classified as described by Jaradat et al [14]. Among the 165 isolates; 6 (4\%), 6 (4\%), 39 (23\%), 99 (60\%), and $15(9 \%)$ isolates were classified as very weak, weak, moderate, strong, and very strong producers, respectively (Fig. 2).

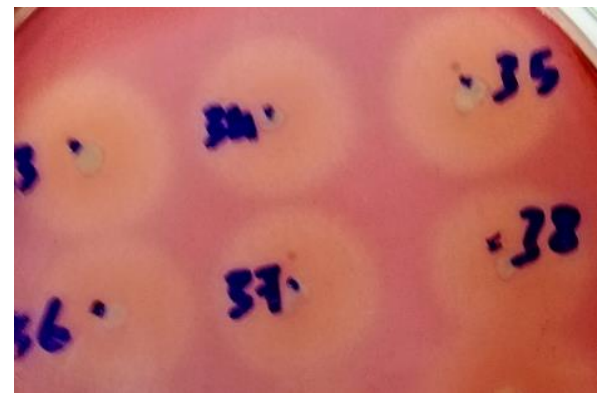

Fig. 1. Different CMC agar plates showing clear zones results from cellulase production by different Streptomyces isolates using Congo red technique.

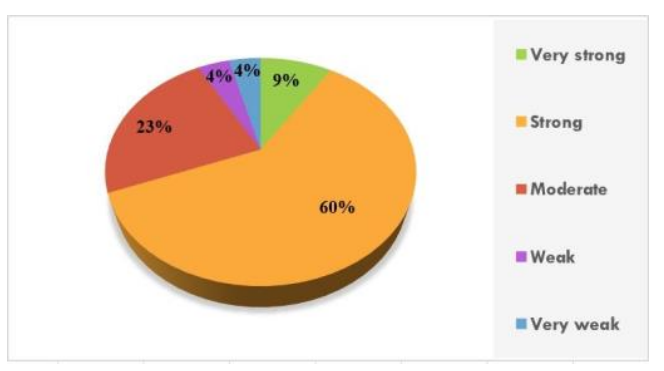

Fig. 2. Levels of cellulase production of the selected Streptomyces isolates $(\mathrm{n}=167)$ by using Congo Red Method; $9 \%$ evaluated as very strong, $60 \%$ as strong, $23 \%$ as moderate, $4 \%$ as weak and $4 \%$ as very weak producers. 


\subsection{Quantitative Determination of Cellulase cellulase-producing Streptomyces isolates $(\mathrm{n}=$ Production by the Selected Streptomyces 15). According to the obtained results, the Isolates cellulase productivity by the tested isolates was \\ The DNS assay was used for quantitative evaluation of the enzymatic activity of strong- ranged from 146.9 to $650.5 \mathrm{U} / \mathrm{L}$ (Table 1). The isolate coded S11-6 showed the maximum cellulase productivity.}

Table 1. Quantitative determination of cellulase activity and specific productivity of the selected Streptomyces producers of highest productivity using DNS assay

\begin{tabular}{cccc}
\hline Isolate & Cellulase activity $\left(\mathbf{U}^{*} / \mathbf{L}\right)$ & Dry cell weight $(\mathbf{g} / \mathbf{L})$ & $\begin{array}{c}\text { Specific productivity } \\
(\mathbf{U} / \mathbf{g})\end{array}$ \\
\hline S11-6 & $650.48 \pm 3.41$ & 1.97 & 330.19 \\
S33-1 & $626.58 \pm 42.74$ & 2.93 & 213.85 \\
S07-1 & $590.72 \pm 18.45$ & 2.6 & 227.20 \\
S24-1 & $577.48 \pm 54.47$ & 0.97 & 595.34 \\
S08-3 & $496.4 \pm 26.23$ & 1.47 & 337.69 \\
S13-3 & $492.52 \pm 54.67$ & 1.43 & 344.42 \\
S18-1 & $478.95 \pm 81.81$ & 2.3 & 208.24 \\
S41-1 & $461.83 \pm 25.59$ & 0.93 & 496.60 \\
S26 & $445.04 \pm 41.3$ & 2.03 & 219.23 \\
S02-3 & $444.07 \pm 25.94$ & 0.97 & 457.80 \\
S25 & $423.39 \pm 21.25$ & 2.33 & 181.71 \\
S15-1 & $368.15 \pm 27.34$ & 2.4 & 153.40 \\
S08-1 & $261.88 \pm 77.87$ & 3.97 & 65.58 \\
S03-1 & $208.58 \pm 58.74$ & 2.77 & 75.30 \\
S30-7 & $146.88 \pm 36.83$ & 3.1 & 47.38 \\
\hline
\end{tabular}

Table 2. Evaluation of the cellulase productivity of the obtained mutants compared to the wild type strain using Congo Red method

\begin{tabular}{ccccc}
\hline Isolate & No. of obtained mutants & \multicolumn{3}{c}{$\begin{array}{c}\text { No of mutants } \\
\text { (Percentage) }\end{array}$} \\
& Lower & Equal & Higher \\
\hline S. coelicoflavus & 45 & 32 & 8 & 5 \\
& & $(71 \%)$ & $(18 \%)$ & $(11 \%)$ \\
\hline
\end{tabular}




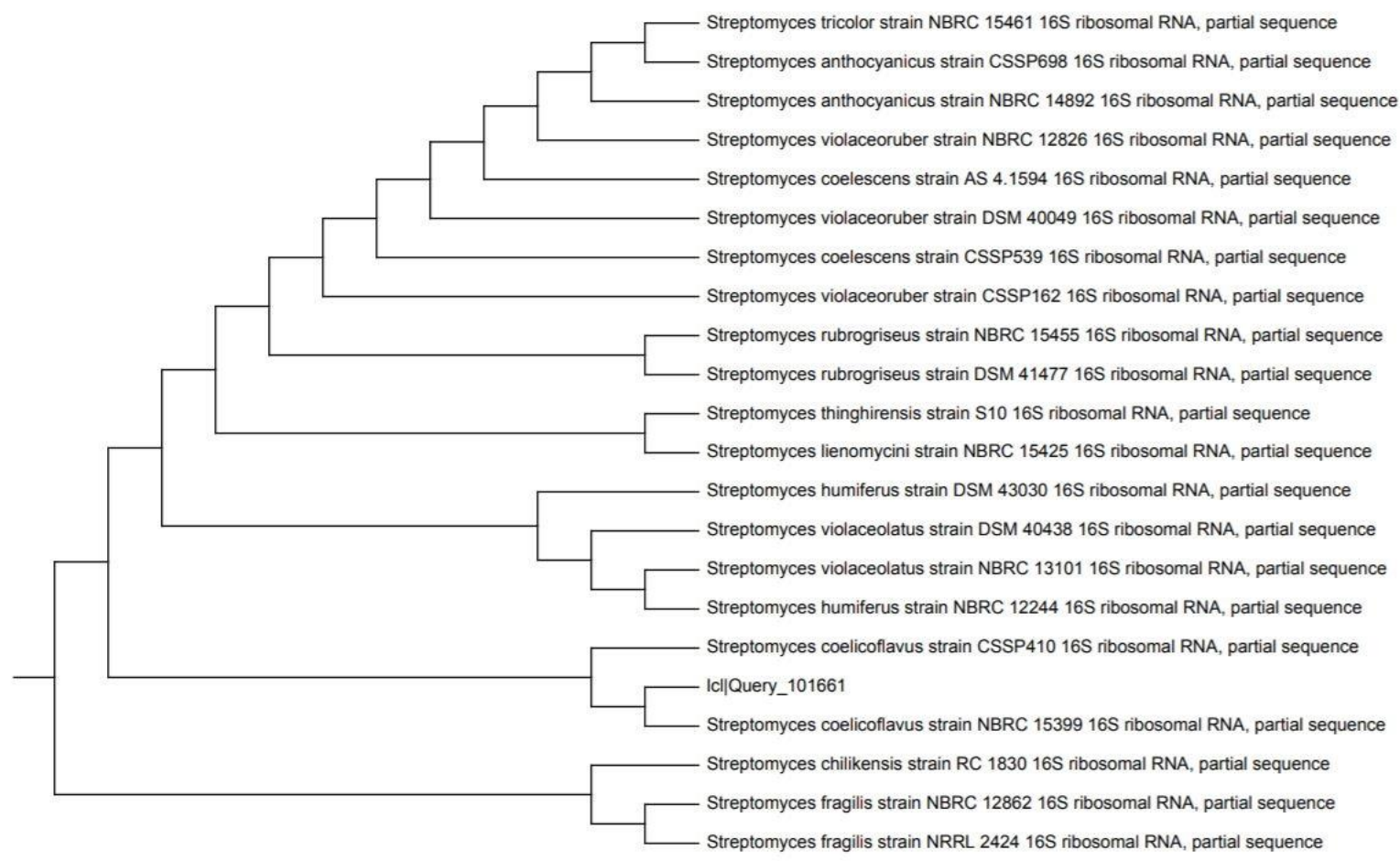

Fig. 3. Neighbor-joining tree showing the phylogenetic position of Streptomyces 11-6 and related species based on partial 16S rRNA gene sequence

\subsection{Identification of the Selected Streptomyces Isolate Coded S11-6}

The selected isolate (S11-6) was identified by 16S rRNA gene sequencing and deposited in the NCBI GenBank database under the accession number NR041175.1. It was identified as Streptomyces coelicoflavus strain NBRC 15399 with $99.9 \%$ homology of the 16S rRNA nucleotide sequence. The phylogenetic tree (Fig. 3) revealed that $S$. coelicoflavus is the closest isolate in similarity to the above-mentioned strain.

\subsection{Improvement of The Enzyme Production of $S$. coelicoflavus by Gamma Irradiation}

This was accomplished by exposing $S$. coelicoflavus to various gamma radiation dosages. According to the obtained results, the optimum dose of gamma radiation for the mutation that resulted in a 99.99 percent kill was 4 KGy. The grown colonies were selected for cellulase production testing.

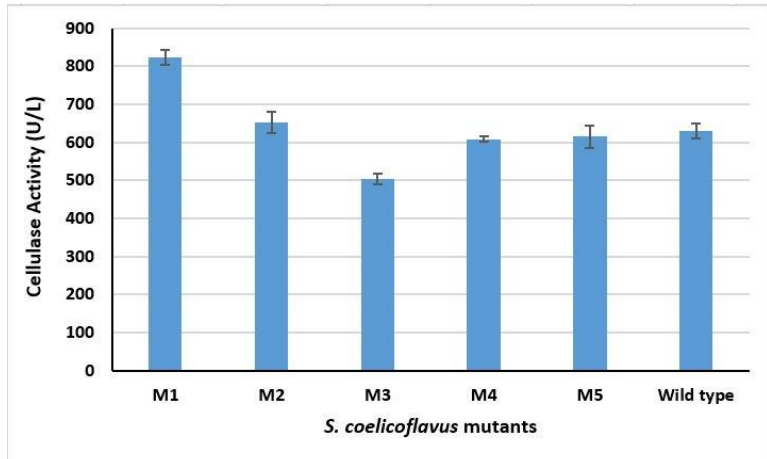

Fig. 4. Evaluation of cellulase activity of the selected mutants (M1-M5) using DNS assay as compared to that of $S$. coelicoflavus wild type.

The cellulase productivity of the obtained mutants was tested by Congo red method. The results revealed that the tested mutants had 
different degrees of cellulase production (Table

2). As compared to the wild-type strain, mutants with higher enzymatic productivity $(n=5)$ were chosen for the quantitative determination of their cellulase productivity by using DNS Assay. According to the obtained results (Fig. 4), only the M1 mutant showed an increase in the cellulase productivity (823.1 U/L), while M2, M4, and M5 approximately had the same cellulase production level as compared to the wild type strain. On the other hand, M3 showed a significant decrease in cellulase production as compared to the wild-type strain.

\section{DISCUSSION}

Cellulase is one of the most significant industrial carbohydrates due to its various applications in several industrial sections. In this context, the selection of microorganisms and process techniques are of essential importance for a thriving industrial production of cellulases [19]. The species Streptomyces have been implicated over the years as a producer of numerous metabolites and biomolecules, including hydrolytic enzymes [20]. Different strains of Streptomyces $\mathrm{sp}$. have been examined and proven to be good producers of cellulase $[12,16,21]$. Streptomyces sp. can be isolated from soil, compost, and water, among other sources. Streptomyces is the most prevalent soil microbe as it approximately accounts for $95 \%$ of the soil microbial isolates [22].

In this study, 43 soil samples were collected from different Egyptian governorates. A total of 165 isolates were recovered and demonstrated the typical growth of Streptomyces sp. (colorful chalky appearance with hard textures). All of them could produce cellulase as they grow on CMC agar medium, a selective media for cellulase-producing microorganisms. The productivity of enzyme-producing microbial strains is closely linked to enzyme production costs. As a result, finding microorganisms with high enzyme productivities was critical [23].

Congo red method was conducted to confirm the ability of the recovered isolates to produce cellulase. Congo red interacts strongly with polysaccharides containing contiguous $\beta-(1-4)$ bound-glucopyranosyl units as CMC. When cellulase-producing isolates grow on CMC agar plates, they hydrolyze $\mathrm{CMC}$ around their growth into smaller fragments than cellohexaose to which Congo red doesn't bind so clear zones formed [24]. Although overall strain growth rates on CMC agar medium are similar, a large variation in cellulase activity has been determined in the tested Streptomyces isolates, ranging from very strong cellulase producers to very weak producers. The very strong producers $(n=15)$ were subjected to a more quantitative test for characterizing their cellulase productivities using DNS assay. The use of DNS assay to detect cellulase activity is very common. The enzymatic hydrolysis of $\mathrm{CMC}$, which liberates reducing sugars, is the basis for this approach. In an alkaline medium, 3, 5-dinitrosalicylic acid (yellow color) oxidizes the aldehyde functional group of these reducing sugars, which itself is reduced to 3-amino-5-nitrosalicylic acid (orangered). The absorbance of the orange-red color of 3-amino-5-nitrosalicylic acid is measured colorimetrically at $540 \mathrm{~nm}$ [25].

The S11-6 isolate that showed the maximum cellulase production was selected for further studies. It was identified by using 16S rRNA gene sequencing. The most prevalent method for detecting bacteria or building bacterial phylogenetic relationships is 16S rRNA gene sequence analysis [26]. This could be due to a variety of factors; first, the existence of this gene in practically all bacteria, frequently as a multigene family, or operons. Second, the 16S rRNA gene's function has remained constant over time, implying that random sequence changes are a more accurate measure of evolution. Finally, 
the $16 \mathrm{~S}$ rRNA gene $(1,500 \mathrm{bp})$ is large enough to be used in informatics [27]. The selected isolate (S11-6) with the highest cellulase productivity was identified Streptomyces coelicoflavus with close genetic proximity to strain NBRC 1539.

Regarding strain improvement, random mutagenesis and fermentation screening have been reported as promising ways to boost the metabolic activity of microorganisms [28]. As a result, inducing mutations in the chosen isolate, $S$. coelicoflavus, may be beneficial in obtaining mutants with increased cellulase productivity. There are various mutagens either chemical, such as N-methyl-N-nitro-N-nitroso guanidine, or physical, such as UV or Gamma irradiation. The limitation of chemical mutagens' use is due to its ability to induce G/C-to-A/T transitions mutations resulting in amino acid substitutions that affect protein structure and function as well as truncation changes that prevent protein activity. Moreover, UV light appears to be a weak mutagen [18]. Accordingly, gamma irradiation was selected for mutation induction.

The use of gamma radiation mutation induction was documented previously by several investigators. Treatment of Aspergillus niger by using gamma irradiation causes an increase in lipase and glucose oxidase productivity by 3.11 and 3.66 fold as compared to the wild-type strain [28, 29]. Furthermore, Lv et al [30] documented 7.6 fold increase in adriamycin production by Streptomyces viridochromogenes using gamma radiation. Moreover, 1.44 fold increase in paromomycin production by Streptomyces rimosus was reported by Ibrahim et al [31].

In the present study, the chosen isolate $S$. coelicoflavus was treated by different doses of Gamma radiation. The dose of $4 \mathrm{KGy}$ was successful to kill 99.99 percent of microbial cells, after which the grown mutants were selected and their cellulase activity was evaluated. M1 mutant could increase the cellulase activity by 1.31 fold when compared to the wild-type strain.

\section{Conclusion}

The soil-isolated $S$. coelicoflavus can be considered a promising candidate for cellulase production and scaling-up. Improvement of cellulase production was achieved by mutagenesis using gamma radiation. A mutant coded M1 showed about 1.31 fold increase in cellulase production. The developed $S$. coelicoflavus-M1 mutant could be exploited as a possible industrial strain for cellulase production in future studies.

\section{Acknowledgment}

We would like to thank all staff of the Microbiology and Immunology Department, Faculty of Pharmacy; Ain shams University for the availability of chemicals, other materials, and instruments that were used for completing the present study.

\section{Declarations}

\section{Ethics approval and consent to participate}

Not applicable

\section{Consent to publish}

All authors have read and agreed to the published version of the manuscript.

\section{Availability of data and materials}

Data analyzed during this study are all included in the main manuscript.

\section{Competing interests}

No competing interests were declared by the authors.

\section{Funding statement}

No funding source was received

\section{REFERENCES}

1. Sankarraj N, Nallathambi G. Enzymatic biopolishing of cotton fabric with free/immobilized 
cellulase. Carbohydr Polym, 2018; 191: 95-102. https://doi.org/10.1016/j.carbpol.2018.02.067

2. Chandrasekaran M. Valorization of food processing by-products. CRC Press, 2012. ISBN: 9781138199422

3. Kumar S. Role of enzymes in fruit juice processing and its quality enhancement. Adv Appl Sci Res, 2015; 6(6): 114-24. ISSN: 0976-8610

4. Anoop Kumar V, Suresh Chandra Kurup R, Snishamol C, Nagendra Prabhu G: Role of Cellulases in Food, Feed, and Beverage Industries. W: Parameswaran B, Varjani S, Raveendran S, red. Green Bio-processes Energy, Environment, and Sustainability. Singapore: Springer Singapore; 2019, s. 323-43. https://doi.org/10.1007/978-98113-3263-0_17

5. Sethi S, Datta A, Gupta BL, Gupta S. Optimization of cellulase production from bacteria isolated from soil. Int Sch Res Not, 2013; 2013. https://doi.org/10.5402/2013/985685

6. Aboul-Enein A. Purification and characterization of a novel thermoactive cellulase from thermophilic actinomycetes isolated from soil sample of Egypt. Int J Acad Res, 2010; 2(1): 6.

7. Álvarez C, Reyes-Sosa FM, Díez B. Enzymatic hydrolysis of biomass from wood. Microb Biotechnol 9: 149-156., 2016. https://doi.org/10.1111/1751-7915.12346

8. Joshi B, Joshi J, Bhattarai T, Sreerama L: Currently Used Microbes and Advantages of Using Genetically Modified Microbes for Ethanol Production. W: Bioethanol Production from Food Crops. Elsevier; 2019, s. 293-316. https://doi.org/10.1016/B978-0-12-8137666.00015-1

9. Lübeck M. Cellulases: Methods and Protocols. New York, NY: Springer New York, 2018. ISBN: 978-1493978762

10. El-Sersy NA, Abd-Elnaby H, Abou-Elela GM, Ibrahim $\mathrm{H}$ a. H, El-Toukhy NMK. Optimization, economization, and characterization of cellulase produced by marine Streptomyces ruber. Afr J Biotechnol, 2010; 9(38): 6355-64. ISSN: 1684-
5315

11. Kara Ö, Bolat İ, Çakıroğlu K, Öztürk M. Plant canopy effects on litter accumulation and soil microbial biomass in two temperate forests. Biol Fertil Soils, 2008; 45(2): 193-8. https://doi.org/10.1007/s00374-008-0327-x

12. Yassien MA-M, Asif AMJ-F, Hani ZA. Production, purification, and characterization of cellulase from Streptomyces sp. Afr J Microbiol Res, $\quad 2014 ; \quad 8(4)$ : 348-54. https://doi.org/10.5897/AJMR2013.6500

13. Ahmad T, Sharma A, Gupta G, Mansoor S, Jan S, Kaur B I wsp. Response surface optimization of cellulase production from Aneurinibacillus aneurinilyticus BKT-9: An isolate of urban Himalayan freshwater. Saudi J Biol Sci, 2020; 27(9): 2333-43. https://doi.org/10.1016/j.sjbs.2020.04.036

14. Jaradat Z, Dawagreh A, Ababneh Q, Saadoun I. Influence of Culture Conditions on Cellulase Production by Streptomyces Sp (Strain J2), 2008; 1(4): 6. ISSN:1995-6673

15. Swathy R, Rambabu K, Banat F, Ho S-H, Chu DT, Show PL. Production and optimization of highgrade cellulase from waste date seeds by Cellulomonas uda NCIM 2353 for biohydrogen production. Int J Hydrog Energy, 2020; 45(42): 22260-70.

https://doi.org/10.1016/j.ijhydene.2019.06.171

16. Budihal SR, Agsar D, Patil SR. Enhanced production and application of acidothermophilic Streptomyces cellulase. Bioresour Technol, 2016; 200: 706-12. https://doi.org/10.1016/j.biortech.2015.10.098

17. Kumar S, Stecher G, Li M, Knyaz C, Tamura K. MEGA X: Molecular Evolutionary Genetics Analysis across Computing Platforms. Mol Biol Evol, $\quad 2018$; 35(6): 1547-9. https://doi.org/10.1093/molbev/msy096

18. Khaliq S, Akhtar K, Ghauri MA, Iqbal R, Khalid AM, Muddassar M. Change in colony morphology and kinetics of tylosin production after UV and gamma irradiation mutagenesis of Streptomyces fradiae NRRL-2702. Microbiol Res, 2009; 164(4): 
469-77.

https://doi.org/10.1016/j.micres.2007.02.005

19. Fang H, Zhao C, Song X-Y, Chen M, Chang Z, Chu J. Enhanced cellulolytic enzyme production by the synergism between Trichoderma reesei RUT-C30 and Aspergillus niger NL02 and by the addition of surfactants. Biotechnol Bioprocess Eng, 2013; 18(2): 390-8. https://doi.org/10.1007/s12257-012-0562-8

20. Fatokun E, Nwodo U, Okoh A. Classical Optimization of Cellulase and Xylanase Production by a Marine Streptomyces Species. Appl Sci, 2016; 6(10): 286. https://doi.org/10.3390/app6100286

21. Sinjaroonsak S, Chaiyaso T, H-Kittikun A. Optimization of Cellulase and Xylanase Productions by Streptomyces thermocoprophilus TC13W Using Low-Cost Pretreated Oil Palm Empty Fruit Bunch. Waste Biomass Valorization, 2020; 11(8): 3925-36. https://doi.org/10.1007/s12649-019-00720-y

22. Gohain A, Manpoong C, Saikia R, De Mandal S: Actinobacteria: diversity and biotechnological applications. W: Recent Advancements in Microbial Diversity. Elsevier; 2020, s. 217-31. https://doi.org/10.1016/B978-0-12-8212653.00009-8

23. Liu X, Kokare C: Microbial Enzymes of Use in Industry. W: Biotechnology of Microbial Enzymes. Elsevier; 2017, s. 267-98. https://doi.org/10.1016/B978-0-12-8037256.00011-X

24. Sazci A, Erenler - Kastro K, Radford A. Detection of cellulolytic fungi by using Congo red as an indicator: A comparative study with the dinitrosalicyclic acid reagent method. J Appl Microbiol, 2008; 61: 559-62. https://doi.org/10.1111/j.13652672.1986.tb01729.x

25. Saqib AAN, Whitney PJ. Differential behavior of the dinitrosalicylic acid (DNS) reagent towards mono- and di-saccharide sugars. Biomass Bioenergy, 2011; 35(11): 4748-50. https://doi.org/10.1016/j.biombioe.2011.09.013
26. Matsumoto T, Sugano M. [16S rRNA gene sequence analysis for bacterial identification in the clinical laboratory]. Rinsho Byron, 2013; 61(12): 1107-15. PMID: 24605544

27. Sune D, Rydberg H, Augustinsson ÅN, Serrander L, Jungeström MB. Optimization of $16 \mathrm{~S}$ rRNA gene analysis for use in the diagnostic clinical microbiology service. J Microbiol Methods, 2020; 170: 105854. https://doi.org/10.1016/j.mimet.2020.105854

28. Zia MA, Rasul S, Iftikhar T. Effect of gamma irradiation on aspergillus niger for enhanced production of glucose oxidase, 2012: 6. ISSN: 0556-3321

29. Iftikhar T, Niaz M, Hussain Y, Abbas SQ, Ashraf I, Zia MA. Improvement of selected strains through gamma irradiation for enhanced lipolytic potential. Pak J Bot, 2010; 42(4): 2257-67. https://doi.org/10.1127/0029-5035/2010/00910265

30. Lv X-A, Jin Y-Y, Li Y-D, Zhang H, Liang X-L. Genome shuffling of Streptomyces viridochromogenes for improved production of adriamycin. Appl Microbiol Biotechnol, 2013; 97(2): 641-8. https://doi.org/10.1007/s00253-0124322-7.

31. Ibrahim A, Aboshanab K, Yassien M, Hassouna $\mathrm{N}$. Improvement of paromomycin production by Streptomyces rimosus subsp paromomycin NRRL 2455 using gamma irradiation mutagenesis. Arch Pharm Sci Ain Shams Univ, 2017; 1(2): 26-30. https://doi.org/ 10.21608/APS.2017.11017 